\title{
EXISTING FORMS OF SOCIAL ENTERPRISES IN HUNGARY WITH PARTICULAR REGARD TO SOCIAL COOPERATIVES
}

\section{Barakonyi, E.}

Communal forms of employment have deep roots in Europe; however, these definitions have not been clarified in Hungary yet. This is partly due to the lack of exposure, and partly due to the lack of a proper, sophisticated regulation framework. The goal of this paper is to organize general terms and aims, introduce the institutional environment, and to highlight problematic areas.

\section{Definition}

The definition of social enterprises, while not widespread in Hungary, is of noteworthy importance in the field of employment in many European countries. According to certain surveys, European social economy provides employment to around $6 \%$ of the active, working age population, but only $2 \%$ of the same group in Hungary (EMES, 2008, p. 28).

\section{Forms of Social Enterprises: Non-profit, or For-profit?}

Certain models of social enterprises have established strong traditions in many countries, and have become accepted tools of handling certain issues of employment, since they contain ventures which aim to solve social issues in a financially sustainable way.

Social enterprises can be non-profit organizations, which utilize business models to reach their primary goals, or they can be business enterprises, which strive to make a significant social impact aside from their business goals. Their principle is the dual optimization of coordinating and balancing their social and economic goals. The basic cornerstone of social enterprises is the establishment of real values: in order to serve sustainability, they must be created to serve real market demands while maintaining their social goals (such as the employment of persons with changed working ability), and to provide competitive, quality products and services. As such, social enterprises function to realize their business and social goals together, while maintaining their balance (Varga, 2011).

In order to achieve success, it is indispensable to pay due attention to business considerations and financial goals while maintaining social goals. Social impact can be increased if the organization launches a venture that directly serves their original mission not just by providing additional sources.

During the lifespan of social enterprises, social and financial goals may sometimes conflict. In the case of a social enterprise operated by a non-profit organization, social goals are prioritized in most cases and financial goals are marginalized, while in the case of a social enterprise functioning in the financial sector, it is more common that profit goals take precedence. In a real social enterprise however, despite the fact that priorities 
may shift occasionally on a case by case basis, the continuous struggle to uphold a balance of goals is maintained: after all, the social impact of the enterprise is the decisive benchmark of success in every case (Bak, 2013, p. 19).

Social enterprises are not a new invention. Several forms have existed under different names and definitions for over two decades in European countries. The wide array of official and unofficial definitions signals a variety of approaches, and is a source of a great deal of confusion to this very day. Terminology is diverse: social business, social enterprise, social venture, social economy, social provider, social company, and social firm. These names often form on a basis of similar general elements, but at the same time they accentuate a trait that is important enough to them to warrant a distinction. Social firms, as they are known, are an example of market-oriented enterprises that are created for the express purpose of providing quality employment to people struggling with disadvantages on the labor market.

Even nowadays, there is no unified definition in the European Union, which leads to practices in member states being widely different. The United Kingdom, which most likely has the most advanced social enterprise sector in the European Union, uses a general, inclusive definition: Social enterprises are ventures that are established with a focus on social and/or environmental goals. They pursue business activities, and their main income is from the sale of goods and services, not donations. Successful social enterprises produce profit, which is then invested into accomplishing their social goals. Their wealth may often exclusively be used to advance the goals of the community (Social Enterprise UK, 2016).

\section{Social Business Initiative}

For the purposes of a unified European judgement of social enterprises, the definition agreed upon as part of the Social Business Initiative measure in 2011 by the European Union is of great importance. This is a suitable starting point which, for now, invalidates the need for a separate Hungarian definition. The definition for social enterprises set by the Social Business Initiative contains the majority of important elements without being overly restrictive: "Social enterprises serve the interests of the community (social, environmental) and not the maximization of profits. By way of their goods and services, as well as the production or organizational methods they employ, they often promote an innovative approach. They often provide employment opportunities to those most marginalized by society. As such, they contribute to social cohesion, employment, and the reduction of inequalities" (European Commission, 2011).

This definition only contains market orientation in a reduced capacity, although it is a very important element especially worth noting for the purposes of sustainability. Still, the common European definition is a large leap forward, which greatly supports the understanding and spreading of the model in every member state of the Union. It is not inconceivable that this will lead to regulation supporting social enterprises which will aid social enterprises in acquiring resources previously difficult to reach in both the private and the public sector.

A comprehensive definition is also useful to entrepreneurs and employees in this sector both, since it enables the formation of a diverse society surrounding social enterprises, which would become a major strength of the sector. 
The Hungarian business sector also sees an increase in businesses that - though their organization is businesslike - are governed by the realization of a social goal as well. These enterprises are not the same as enterprises that are socially conscious, or operating with a socially conscious program. Social enterprises are different from these businesses in that their operation makes social and environmental goals a building stone of their business concept, making it an equal of profit goals (Egyed, 2010, p. 6).

\section{Forms of Social Enterprises}

In Hungary, no specific legal form or status is associated with social enterprises. They may take on many kinds of legal forms, with all the advantages and disadvantages each has. This results in a diverse selection that is beneficial to the advancement of the sector, since it enables innovation and experimentation. The most important related legal regulations are as follows:

- For foundations and associations, the Civil Code (Section 11 of Act CLXXV of 2011 on the right of association, non-profit legal standing) contains further regulations with regards to civilian organizations, including associations and foundations important to us.

- The Civil Code regulates the functioning of economic businesses.

- Social cooperatives are regulated by laws on cooperatives (Act X. of 2006, Acts V. and CLXXVII. of 2013).

- Tax responsibilities of nonprofit organizations are described in different tax legislation. Hungarian laws allow nonprofit organizations to pursue economic, entrepreneurial activities, but only in a complementary manner, and only for as long as it does not threaten the original goal of the organization. Regulation concerning the management of civilian organizations is lenient; however, there are obstacles hindering actualization, for example in taxation and labor law. Social enterprises are not subject to discriminative tax regulations, but neither do they enjoy any special benefits, unless they have some sort of a special status, such as existing for public benefit. Nonprofit social enterprises may be exempt from corporate tax, if their business activities can be classified as existing for public benefit. Social enterprises do not enjoy any tax benefits, regardless of their proceeds and goals being social. This form is as such rarely applied at the start, it is more likely that enterprises created as business ventures realize that they are social enterprises in reality. It is in part due to these issues of self-definition that determining the number of social enterprises in Hungary is so difficult. As for nonprofit business companies: they may only pursue economic business activities as a complementary measure, if profit from company activities cannot be divided among members, it is added to the wealth of the company. Complementary nature is a strange restrictive exception, since it limits the growth of the company, in turn limiting their social impact, and force the nonprofit company to "dress up" their business activities as "goal based activity", or to always have significant non-price income profit. In social enterprises, this can unfortunately lead to the fragmentation of resources, if management is constantly tasked with traditional source management as well. The explanation lies in the fact that the majority of nonprofits in Hungary nowadays are in reality the legal successors of public 
companies, and as such most of them are not independent from the public sector and do not operate in a market-oriented manner. For newly forming organizations, the legal form of a nonprofit business company is available, and could be an important alternative for social enterprises. This is true if the social enterprise in question wishes to mostly support itself through donations and state grants, or if they are able to find owners and investors who are interested in reinvesting the potential gains of business activities in order to fund social utility, and not in the acquisition of these profits. In this way, the form of nonprofit business companies are a kind of barrier for a social enterprise intending on including market capital, since they narrow down the circle of investors available to them. Many social enterprises decide to instead opt for the foundation of a business company, and record their social commitments and goals in another way, such as a company agreement.

Legislation relating to the entrepreneurial activities of different legal forms of companies exists across different legal regulations, which are often not coordinated with one another. Due to the uncertainty of related terms - such as business activity, economic and entrepreneurial activity as used in Hungarian law, business-like economic activity concerning measures of entrepreneurial activity, be it registry or tax-paying responsibilities, a lot is left to judicial practice.

\section{Social Cooperatives}

Act X. of 2006 on cooperatives contains the measures pertaining to social cooperatives, and the Civil Code contains background regulations. This regulation clarifies the basic difference between cooperatives and economic companies, noting that a cooperative is not a special case of an economic company. Despite the fact that both cases are gain-oriented, economic companies are only concerned with profit, while members of a cooperative focus on the unity of fulfilling their economic, cultural, social, educational, healthcare necessities and desires together. In an economic company, profits are distributed according to the ratio of monetary contributions, meanwhile a set amount of a cooperative's income is put into an indivisible community fund, and the rest is given to the members partly in accordance with their cooperation and partly with regards to their monetary contributions (Lórodi, 2014, p. 19). An economic company usually does not generate monetary funds to be used to support community goals, but with cooperatives the community fund serves this purpose, paying for the taxes and contributions of, and providing benefits and support to members and their relatives. Taking part in decision-making in the case of an economic company is usually determined by contribution, but in cooperatives each member gets one vote only (Ferencz, 2015, p. 67). As per the relevant legal measures, a cooperative is an association founded with a set amount of capital, operates on the basis of open membership and changing capital, which functions with a legal personality, in order to aid in fulfilling the economic and other social (cultural, educational, social, healthcare) needs of its members.

The latest result of the legal development of cooperatives is the social cooperative and the employment cooperative (a form of social cooperative with at least 500 natural persons and at least one minority council as its members), which differ from the classic functions of cooperatives in that their activities are defined by attempting to improve the social situation of marginalized sections of society. Legislation recognizes the following 
as social cooperatives: cooperatives creating employment opportunities for disadvantaged members, those attempting to improve the social situations of their members, as well as school cooperatives that organize employment for students (Except from Section 13.3. of Act X. of 2006. Ministerial Justification). In accordance with this, a social cooperative is one that tasks itself with creating employment opportunities for its disadvantaged members, that otherwise strives to improve their social standing, or that functions as a school cooperative.

\section{Civilian Association}

Civilian associations were introduced as a new form of institutional organization. According to Section 578/J of the Civil Code, natural persons may create an association to further their common, non-economic goals, and to coordinate their community-driven activities. This form may be created even without any monetary contributions. Practical differences between regulations concerning civilian associations and companies constituted under civil law are that the association may be disbanded by any member with no justification necessary, except for the member designated in the association agreement as a designated conductor of business, and the association at the event of the resignation or death of a member if this reduces the number of members to one. The main difference between the two is that civilian associations may not be founded primarily for economic activity, and may not primarily conduct economic activity. Aside from this, civilian associations are considered companies constituted under civil law, which is not registered and do not constitute a legal person. For this reason, it is important to note that this form of organization may not acquire legal standing as public benefit.

By overviewing certain organizational forms, we can ascertain that gauging possibilities is best done at the time of setting goals, in the beginning. With foundations, the focus is on managing funds for a certain goal, while with associations it is the management of the activities of a community. Nonprofit economic companies are viable for projects with bigger scopes, and social cooperatives are adept at handling a common struggle to aid disadvantaged members of a community in finding employment. With civilian associations, emphasis is on grassroots initiatives.

\section{The Question of Public Benefit}

Organizations operating in the nonprofit sector - foundations, civilian associations, nonprofit economic companies, as well as social cooperatives outside the sector - are eligible for certain benefits concerning taxes, duties and customs requirements for certain activities in recognition of their social role and nature of existing for public benefit, as well as to aid their function. Public benefit quality is awarded to an organization, which meets the following requirements in the Civil Code: a registered organization in Hungary that performs activities for the public benefit with adequate means to fulfill the communal necessities of the individual, which furthermore is able to demonstrate proper social support, and which is a civilian organization (not including civilian associations) or an organization which is allowed to gain the legal standing of pubic benefit by law (for example nonprofit ltd.). Adequate means constitute fulfilling at least one of the following requirements, concerning the last two completed fiscal years of the organization: 
1. the average annual income is over 1 million Forints (ca. 3500 EUR) or

2. the aggregated post-tax profit of two years is not negative or

3. personal expenses amounts to at least a quarter of total expenditures.

Additionally, support from the public must be demonstrated, which constitutes fulfilling one of the following requirements, concerning the last two completed fiscal years of the organization:

1. revenue from $1 \%$ of personal income tax reaches $2 \%$ of total income excluding grants from governmental subsystems, or

2. expenses from public benefit activities amount to at least half of all average expenditures of two years, or

3. in the average of two years, public benefit activities are handled by at least 10 volunteer workers, in accordance with legislation on volunteer activity for public benefit.

Charitable activity to be performed by the civilian association are to be defined in the founding document (the association's statutes, the foundation's articles of association). According to the Civil Code, all activities are considered for the pubic benefit if they directly or indirectly serve the charitable tasks noted in the founding document, contributing to the fulfillment of society and the individual's communal necessities. Public functions are state or council tasks defined in legislation, which are completed for the public benefit, not for profit, and in accordance with the requirements and conditions of law.

The two endpoints of forms of social enterprises detailed here are then economic companies on the one end, and organizations performing no economic activity at all on the other. However, economic companies may not enjoy benefits awarded to organizations with a social quality, leading to their social activities manifesting in the sector of social consciousness instead. Other social enterprises build their framework specifically around public benefit, and profits become entirely secondary, in a complementary capacity. Social cooperatives exist as an exception to this.

\section{Types of Social Cooperatives}

Section 14 of act X. of 2006 on cooperatives defines social cooperatives as an association that aims to create employment opportunities for its disadvantaged members, as well as to otherwise improve their social standing. School associations used to also be considered as social cooperatives, however with the new Civil Code, they are no longer a part of this category.

In Hungarian practice, the following types of socially inclined cooperatives are defined, as per the work of Németh (2013):

1. Social cooperatives specially focused on ensuring the employment integration of disadvantaged persons, where the suggested membership consists of $70 \%$ of well-situated members, and $30 \%$ of disadvantaged members to be integrated.

2. Social cooperatives focused on local communal necessities, which represent local communal interests and provides for local necessities, as opposed to the globalized self-interests of the market economy. Membership is made up of persons appropriate to local circumstances and activities, as well as possibly offering membership to councils and charitable organizations. 
3. Social cooperatives functioning as communal enterprises, which is a social enterprise maintaining cooperative principles, with a strong emphasis on alternative economic cooperation and alternative communal values to base lifestyles on, as well as a focus on sustainable development.

4. Employment cooperative, with members including at least 500 natural persons and one national minority council (Section 17 paragraph 1 of act X. of 2006) and their work to aid their disadvantaged members in finding employment opportunities is chiefly done by way of temporary staffing and labor mediation. (In accordance with section 17, paragraph 2 of act X of 2006, employment cooperatives create employment opportunities chiefly by way of temporary staffing and labor mediation activities, which are performed in accordance with the regulations of legislation concerning temporary staffing, nonprofit rentals, as well as private labor mediation, with the exception that they may perform temporary staffing activities concerning their own members.)

Employment cooperatives are the only special form of social cooperatives to be named by Act X of 2006 .

\section{The Potential Role of Social Cooperatives in Expanding Employment}

It is worth noting in relation to social cooperatives, that this is the only form of organization where the direct involvement of members in the activities of the group is a legal obligation, and as such the continuous education and training of unemployed or disadvantaged members is provided, increasing their chances of reintegration into the labor market. (Longa, 2009, p. 7.) "Regulations in effect do not contain any measures to limit the economic/business activities of social cooperatives, allowing them to fund themselves through income from their own activities, as well as providing monetary benefits to their members according to the amount of their cooperation in the activities of the cooperative" (Longa, 2009, p. 67.).

This regulation mainly benefits the employer (the cooperative), which in turn may result in an increase of willingness to employ. However, it could be a detriment to the members of the cooperative, since their employment is not regulated by the Labor Code, rather, the charter of the cooperative. This makes the regulations for work hours, rest periods and vacation not obligatory, and also makes overtime inapplicable. Binding employment to the charter also makes the relationship of parties inflexible, since altering the charter is far more difficult than altering a work contract. It is also an absolute detriment to members of cooperatives that minimum wage regulations may also be disregarded, and neither may the tools to protect wages be applied, since these are a part of the Labor Code.

The Hungarian Government intends to prioritize the support of cooperative employment in the future, which will likely increase the number of people employed in this form of employment. With this in mind, it would be prudent to consider the implementation of a few safety regulations to ensure cooperative employment, especially since those working in this form of employment are characteristically disadvantaged, vulnerable people.

Overall, therefore the most important statement of the study is that despite social employment, and more precisely social cooperatives striving to primarily aid the most 
vulnerable and disadvantaged persons in improving their employment situation, the current regulatory environment primarily concerns itself with motivating employers, and as a result, the social security of employees is not sufficient. This is especially true when compared with traditional employment forms.

\section{Note: Referenced Law Documents}

2006. évi X.tv. A szövetkezetekröl

2006.évi V. tv. A cégnyilvánosságról, a bírósági cégeljárásról és a végelszámolásról

2013. évi CLXXVII. tv. A Polgári Törvénykönyvről

\section{References}

Bak, K. (2013). A nemzetközi szövetkezeti alapelvek és a szövetkezet fogalmának összefüggései a szabályozásban. Kézirat. Retrieved December 10, 2016 from http://www. szovetkezetikutato.hu/letoltes/bak_klara.doc.

Egyed, J. (2010). A szociális szövetkezet - a foglalkoztatás új lehetősége. Háló: a Szociális Szakmai Szövetség hírlevele, 16(4), 3-8.

European Commission (2011). Communication from the Commission to the European Parliament, the Council, the European Economic and Social Committee and the Committee of the Regions. Creating a favourable climate for social enterprises, key stakeholders in the social economy and innovation. Retrieved December 16, 2016 from http://ec.europa.eu/ internal_market/social_business/docs/COM2011_682_en.pdf

Ferencz, J. (2015). A szociális szövetkezet tagjainak munkaviszonya. Magyar munkajog, 2015(1), 61-71.

Lórodi, L. (2014). A munkaviszonyon túli foglalkoztatási viszonyok, Szociális szövetkezet, tagi munkavégzési jogviszony. HR \& Munkajog, nov-dec.

Németh, L. (2013). Mi a szociális szövetkezet? Tájékoztató, Szociális Szövetkezetek Országos Szövetsége. Retrieved December 9, 2016 from http://szoszov.hu/ nemeth-laszlo-mi-a-szocialis-szovetkezet.

Social Enterprise UK (2016). Social Enterprise UK - National Body of Social Enterprise. Retrieved June 25, 2016 from http://www.socialenterprise.org.uk/about/ about-social-enterprise/social-enterprise-dictionary\#general.

Varga, É. (2011). A társadalmi vállalkozások ökoszisztémája - nemzetközi példák és jó gyakorlatok 2011. Retrieved December 10, 2016 from http://www.nesst.org/ wp-content/uploads/2014/05/A-t\%C3\%A1 rsadalmi-v\%C3\%A1llalkoz\%C3\%A1 sok\%C3\%B6kosziszt\%C3\%A9m\%C3\%A1ja.pdf.

\section{Author}

\section{Eszter Barakonyi PhD}

Assistant Professor

University of Pécs, Faculty of Business and Economics

Department of Leadership and Organizational Sciences

H-7622 Pécs, Vasvári Pál utca 4.

barakonyie@ktk.pte.hu 